phenothiazines. Although the first patient had no visual impairment or apraxia, computed tomographic appearances were compatible with parieto-occipital infarcts in arterial boundary zones and may have been due to hypotension. ${ }^{3}$ The paroxysms of muscle spasms, tachycardia, sweating, and rage were probably due to brain-stem dysfunction analogous to the "rage reaction" produced experimentally in animals by diencephalic damage or stimulation. ${ }^{4}$ The akinetic mutism, catatonic posturing, and disordered eye movements in the second patient indicated a lesion of the upper brain stem affecting the basal ganglia. ${ }^{5}$

Despite systemic hypotension the clinical features described above are not those expected from lesions in arterial boundary zones but are more in keeping with damage to basal ganglia and diencephalic structures, which are lairly resistant to hypotension. Asphyxic anoxia may affect basal ganglia, and hypoxia may have caused such damage in our cases. In addition, anaphylaxis may cause vasoconstriction or increased vascular permeability, and these mechanisms may have produced lesions in the well-vascularised structures of the brain stem and basal ganglia.

I thank Dr G D Schott for helpful suggestions, and Dr J A Morgan Hughes and Dr Michael Kremer for permission to report on patients under their care.

${ }^{1}$ Kornyey St. Histopathologie und klinische Symptomatologie der anoxischvasalen Hirnschädigungen (Zweite Auflage). Vol 1. Budapest: Akademai Kiado, 1955.

2 Castaigne P, Bertrand I, Buge A, Godet-Guillain J, Escourolle R, Martin $\mathrm{M}$. Coma prolongé secondaire à une piqûre d'insecte nécrose symétrique des putamens ramollissement laminaire cortical étendu. Rev Neurol $1962 ; 107: 401-16$.

${ }^{3}$ Adams JH, Brierley JB, Connor RCR, Treip CS. The effects of systemic hypotension upon the human brain. Clinical and neuropathological observations in 11 cases. Brain 1966;89:235-68.

4 Wheatley MD. The hypothalamus and affective behaviour in cats. Archives of Neurology and Psychiatry 1944;52:296-316.

${ }^{5}$ Denny-Brown D. Diseases of the basal ganglia. Lancet 1960;ii:1009-105.

(Accepted 14 September 1981)

National Hospital for Nervous Diseases, Queen Square, London WC1N 3BG

A N GALE, MB, MRCP, registrar in neurology (present appointment: senior registrar in neurology, University College Hospital, London WC1E 6AU)

\section{Paracetamol-induced acute renal failure in the absence of fulminant liver damage}

Acute renal failure has often been reported ${ }^{1}$ with paracetamol poisoning but usually in association with fulminant hepatic failure. Never- theless, renal failure may develop in the absence of liver failure. We identified 10 such cases and report here the clinical details.

\section{Case reports}

The case notes of all patients presenting with paracetamol overdose during 1974-81 were reviewed. Ten patients were identified who had manifested moderate or severe renal impairment (serum creatinine concentration $>400$ $\mu \mathrm{mol} / 1(4.5 \mathrm{mg} / 100 \mathrm{ml}))$ in the absence of evidence of liver failure such as deep jaundice, encephalopathy, or severe bleeding diathesis (table). In these patients the renal failure could not be attributed to other factors such as septicaemia or ingestion of other potentially nephrotoxic drugs. All but one patient had a period of oliguria (24-hour urine $<500 \mathrm{ml}$ ). In general, renal failure was most evident one week after ingestion compared with two to four days for the liver damage. Liver function, as indicated by the prothrombin time, usually recovered rapidly, and in no case did hepatic dysfunction cause problems in management, as may be seen from the following case report.

Case 3-A 23-year-old woman was admitted 16 hours after taking $17 \mathrm{~g}$ paracetamol. She was initially drowsy, due to alcohol, but her level of consciousness was normal by 12 hours and remained so thereafter. At 48 hours her prothrombin time had fallen to $21 \%$ but two days later it was back to $100 \%$. Creatinine clearance, however, had fallen below $101 / 24 \mathrm{~h}$ (6 $\mathrm{ml} / \mathrm{min}$ ) and peritoneal dialysis was started. Liver biopsy showed centrilobular collapse with some residual necrosis; renal biopsy on the sixth day showed distal tubular necrosis with regenerative changes.

\section{Comment}

To give a truly accurate estimate of the incidence of renal failure after paracetamol overdose is impossible. During the seven years covered by this study 1035 patients were admitted to this hospital after paracetamol overdose and 23 died from liver failure $(2 \cdot 2 \%)$. Perhaps half of these patients, ${ }^{3}$ however, had taken small quantities of the drug, insufficient to produce any toxic effect. Ninety-two patients had been transferred from other hospitals for inclusion in a trial of paracetamol antidote treatment. ${ }^{3}$ In the present series four patients had been referred from other hospitals, including one who was transferred to the renal unit because of renal failure. Thus the incidence of this complication appears to be about $1 \%$ overall or $0.6 \%$ for non-referred patients. When patients who did not develop any liver dysfunction are excluded the incidence is rather higher.

Wilkinson $e t a l^{1}$ found six patients with renal failure out of 90 who had liver damage without fulminant hepatic failure after paracetamol overdose, an incidence of $7 \%$, but the severity of the renal failure was not fully described. One further case has been reported, with results of renal histology and electron microscopy, ${ }^{4}$ and two of the present patients have been mentioned as part of a separate study. ${ }^{5}$ The size of the present series confirms that this pattern of damage after paracetamol overdosage may not be uncommon and highlights the severity of the renal failure that may develop.

The pathogenesis of the renal failure remains uncertain. Interestingly, in four of the seven cases in which it was recorded urine osmolarity was surprisingly low. Increases in plasma renin activity have been reported ${ }^{5}$ and an endotoxinaemic insult implicated. ${ }^{1}$ These factors may act together to produce renal tubular damage. A direct

Clinical details of 10 patients who developed acute renal failure in absence of fulminant liver failure after paracetamol overdose

\begin{tabular}{|c|c|c|c|c|c|c|c|c|c|c|}
\hline $\begin{array}{l}\text { Case } \\
\text { No }\end{array}$ & $\begin{array}{c}\text { Age } \\
\text { (years) }\end{array}$ & $\begin{array}{l}\text { Paracetamol } \\
\text { dose (g) } \\
\text { (time before } \\
\text { admission } \\
\text { (hours)) }\end{array}$ & $\begin{array}{c}\text { Paracetamol } \\
\text { concentration } \\
(\mathrm{mg} / \mathrm{l})\end{array}$ & $\begin{array}{c}\text { Specific } \\
\text { treatment } \\
\text { (time after } \\
\text { admission } \\
\text { (hours)) }\end{array}$ & $\begin{array}{c}\text { Highest } \\
\text { aspartate } \\
\text { transaminase } \\
\text { activity (IU/l) } \\
\text { (day) }\end{array}$ & $\begin{array}{l}\text { Lowest } \\
\text { prothrombin } \\
\text { time }(\%) \\
(\text { day })\end{array}$ & $\begin{array}{l}\text { Urine sodium; } \\
\text { osmolarity } \\
\text { (mmol/l) } \\
\text { (day) }\end{array}$ & $\begin{array}{l}\text { Highest serum } \\
\text { creatinine } \\
(\mu \mathrm{mol} / \mathrm{l})\end{array}$ & $\begin{array}{c}\text { Lowest } \\
\text { creatinine } \\
\text { clearance } \\
(1 / 24 \mathrm{~h})\end{array}$ & $\begin{array}{c}\text { Period of } \\
\text { oliguria } \\
\text { (days) }\end{array}$ \\
\hline 1 & 45 & $12 \cdot 5+12 \cdot 5$ & 48 & Acetylcysteine & 8280 & 17 & $33 ; 200$ & 811 & 6 & $3-5$ \\
\hline $2^{*}$ & 18 & $\begin{array}{c}\text { (12) }{ }_{50}(24) \\
(14)\end{array}$ & 124 & $\begin{array}{c}(14) \\
\text { Cysteamine } \\
(17)\end{array}$ & $\begin{array}{l}\text { (3) } \\
732 \\
(2)\end{array}$ & $\begin{array}{l}(3) \\
41 \\
(2)\end{array}$ & $\begin{array}{c}(5) \\
43 ; \mathrm{NR}\end{array}$ & $\begin{array}{c}1240 \\
\text { (PD } 5 \text { days) }\end{array}$ & 1 & $3-12$ \\
\hline $3^{*}$ & 23 & $\begin{array}{l}17 \\
(16)\end{array}$ & 34 & Placebo & $>1000$ & $\begin{array}{l}29 \\
(2)\end{array}$ & $22 ; \mathrm{NR}$ & $\begin{array}{c}1310 \\
\text { (PD } 8 \text { days) }\end{array}$ & 2 & $3-14$ \\
\hline 4 & 20 & $\begin{array}{l}25 \\
(60)\end{array}$ & NR & & $>2000$ & 27 & NR; NR & 700 & 7 & $2-3$ \\
\hline 5 & 41 & $\begin{array}{c}29 \\
(48)\end{array}$ & NR & & $\begin{array}{c}8440 \\
(2)\end{array}$ & $\begin{array}{l}21 \\
(2)\end{array}$ & $\begin{array}{c}19 ; 292 \\
(4)\end{array}$ & $\begin{array}{c}1080 \\
\text { (PD } 8 \text { days) }\end{array}$ & 2 & $3-11$ \\
\hline 6 & 26 & $\begin{array}{l}10 \\
(12)\end{array}$ & NR & & $\begin{array}{l}260 \\
(3)\end{array}$ & $\begin{array}{l}70 \\
(3)\end{array}$ & $\begin{array}{c}20 ; 294 \\
(4)\end{array}$ & $\begin{array}{c}1460 \\
\text { (PD } 7 \text { days) }\end{array}$ & 1 & $4-12$ \\
\hline 7 & 38 & $\begin{array}{l}50 \\
(6)\end{array}$ & 390 & Placebo & 3980 & 28 & $46 ; 292$ & 560 & 7 & $4-6$ \\
\hline 8 & 17 & 11 & 226 & Placebo & $>5000$ & $\begin{array}{l}33 \\
(2)\end{array}$ & $\begin{array}{c}19 ; 180 \\
(4)\end{array}$ & 480 & 10 & $\begin{array}{c}\text { Not } \\
\text { oliguric }\end{array}$ \\
\hline 9 & 19 & $\begin{array}{c}30 \\
(18)\end{array}$ & NR & & $\begin{array}{c}4200 \\
(2)\end{array}$ & $\begin{array}{l}24 \\
(2)\end{array}$ & $\begin{array}{c}70 ; 210 \\
(7)\end{array}$ & 585 & 8 & $3-4$ \\
\hline 10 & 25 & $\begin{array}{l}50 \\
(8)\end{array}$ & 328 & $\begin{array}{l}\text { Acetylcysteine } \\
\text { (11) }\end{array}$ & 2150 & $\begin{array}{l}12 \\
\text { (2) }\end{array}$ & $\begin{array}{l}66 ; 207 \\
\text { (5) }\end{array}$ & 789 & 5 & $4-7$ \\
\hline
\end{tabular}

$\mathrm{NR}=$ Not recorded. $\mathrm{PD}=$ Peritoneal dialysis.

Renal biopsy performed: histology showed distal tubular damage.

Conversion: SI to traditional units-Sodium: $1 \mathrm{mmol} / 1=1 \mathrm{mEq} / \mathrm{l}$. Osmolarity: $1 \mathrm{mmol} / 1=1 \mathrm{mosmol} / 1$. Creatinine: $1 \mu \mathrm{mol} / 1 \approx 11 \cdot 3 \mu \mathrm{g} / 100 \mathrm{ml}$. 
nephrotoxic effect of paracetamol or its metabolites has also been suggested. ${ }^{4}$ Histology is compatible with either hypothesis.

As in previous reports ${ }^{145}$ all patients in this series had evidence of liver damage, although in at least one (case 6) the changes were slight, and in nearly all patients the prothrombin time was near normal or at least improving when renal failure became fully established. There is clearly a poor correlation between the severity of liver damage and the development of renal failure.

Thus, although liver failure remains the major cause of death from paracetamol overdose, this study emphasises that acute renal failure may occur in the absence of fulminant liver failure and is a source of considerable morbidity in these patients.

${ }^{1}$ Wilkinson SP, Moodie H, Arroyo VA, Williams R. Frequency of renal impairment in paracetamol overdose compared with other causes of acute liver failure. 7 Clin Pathol 1977;30:141-3.

${ }^{2}$ Hamlyn AN, Douglas AP, James OFW. The spectrum of paracetamol (acetaminophen) overdose: clinical and epidemiological studies. Postgrad Med f $1978 ; 54: 400-4$.

${ }^{3}$ Hamlyn AN, Lesna M, Record CO, et al. Methionine and cysteamine in paracetamol (acetaminophen) overdose, prospective controlled trial of early therapy. F Int Med Res $1981 ; 9: 226-30$.

${ }^{4}$ Kleinman JG, Broitenfield RV, Roth DA. Acute renal failure associated with acetaminophen ingestion. Report of a case and review of the literature. Clin Nephrol 1980;14:201-5.

${ }_{5}^{5}$ Wilkinson R, James OFW, Roberts SH, Morley AR, Robson V. Plasma renin activity during the development of paracetamol (acetaminophen) induced acute renal failure in man. Clin Nephrol 1979;11:196-201.

(Accepted 14 September 1981)

Gastroenterology and Renal Units, Department of Medicine, Royal Victoria Infirmary, Newcastle upon Tyne

I COBDEN, MD, MRCP, senior registrar

C O RECORD, DPHIL, FRCP, consultant physician

$M K$ K WARD, $M B, M R C P$, consultant physician

D N S KERR, MSC, FRCP, professor of medicine

\section{Bilateral renal carcinoma}

Renal carcinoma may rarely present simultaneously in both kidneys. We report a case of bilateral renal carcinoma treated by bilatera nephrectomy. After resection one kidney was preserved by hypothermia; the upper-pole tumour was excised while the kidney was cold and the healthy lower pole then reimplanted.

\section{Case report}

A 47-year-old woman presented with intermittent swelling in the neck. Examination showed no abnormality, but a palpable mass was detected in

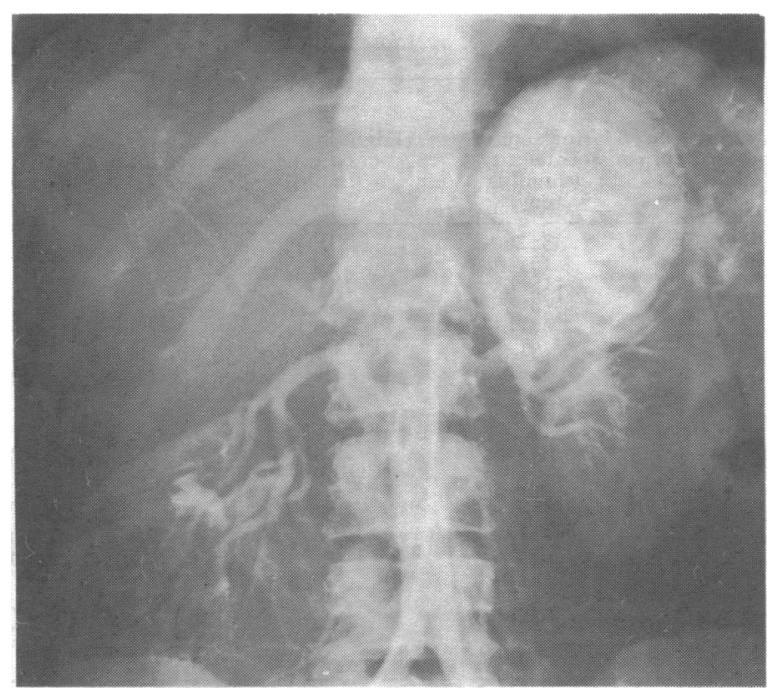

Arteriogram showing tumour in lower two-thirds of right kidney and in upper pole of left kidney. the right side of the abdomen. Excretion urography and renal ultrasound examinations disclosed a space-occupying lesion in both kidneys. Arteriography showed a tumour in the lower two-thirds of the right kidney and a further tumour in the upper pole of the left kidney (figure). No evidence of tumour spread was detected by phlebography, chest radiography, and serum biochemistry or by bone and liver radioisotope scans.

At operation large tumours were found in both kidneys with no evidence of metastasis. Diuresis was promoted with intravenous fluids and frusemide. Bilateral radical nephrectomy was undertaken, but the right adrenal gland was conserved and the left ureter divided at the pelvic brim. The left kidney was cooled by pervascular irrigation and immersion in ice-cold Sacks's sulution II. ${ }^{1}$ Under hypothermic conditions the perinephric fat and the adrenal gland were removed from the kidney and the vessels carefully identified. The tumour, with a margin of normal renal tissue, was excised leaving about half the original normal kidney. The defect in the pelvicaliceal system was closed. The open ends of arteries and venous sinuses were oversewn and the capsular defect closed. The lower pole of the left kidney was reimplanted into the right iliac fossa, with anastomosis of the renal artery with the internal iliac artery and of the renal vein with the external iliac vein. The ureter was reimplanted into the bladder. Intravenous mannitol $10 \mathrm{~g}$ was administered.

She recovered satisfactorily from the anaesthetic, but by the third postoperative day she had passed a total of only $507 \mathrm{ml}$ of urine and serum creatinine concentration had risen to $579 \mu \mathrm{mol} / 1(6.5 \mathrm{mg} / 100 \mathrm{ml})$. A technetium-99m renal scan showed adequate renal perfusion but no excretion. Haemodialysis was started and repeated on the sixth postoperative day. Thereafter the urinary output recovered and by the 18th day serum creatinine concentration was $140 \mu \mathrm{mol} / 1(1.6 \mathrm{mg} / 100 \mathrm{ml})$. When at three months she returned to work her serum creatinine concentration was 128 $\mu \mathrm{mol} / 1$ ( $1.4 \mathrm{mg} / 100 \mathrm{ml})$. At six months excretion urography showed no evidence of recurrent tumour or ureteric obstruction: a chest radiograph remained clear and the serum creatinine concentration unchanged.

\section{Comment}

Nephrectomy is the treatment of choice for renal carcinoma. ${ }^{2}$ In the few cases in which tumours arise simultaneously in both kidneys resection with preservation of enough renal tissue to sustain normal life is the only practical alternative to bilateral nephrectomy and longterm dialysis. A review of the treatment of bilateral tumours ${ }^{3}$ showed that all patients treated by means other than surgery died in less than six months. Those treated by nephrectomy with contralateral partial nephrectomy or by bilateral partial nephrectomy survived longer.

In most cases partial nephrectomy may be undertaken in vivo under hypothermic conditions quite satisfactorily. In this case, however, the large upper-pole tumour made access within the abdomen difficult. Since the tumour occupied half of the kidney the approach to the hilar vessels was further limited. The improved access gained in the isolated organ allowed the vascular supply to the healthy lower pole to be safeguarded. In addition the procedure enabled radical resection of the kidney and surrounding perinephric tissues to be undertaken and only after this had been satisfactorily achieved was the healthy tissue isolated and reimplanted. In view of the increased hazard of the ex-vivo technique it should be reserved for more difficult tumour resections.

We thank Dr R Wilkinson, consultant nephrologist, for his help with this case.

1 Sacks SA, Petritsch PH, Kaufman JJ. Canine kidney preservation using a new perfusate. Lancet $1973 ; \mathrm{i}: 1024-8$.

2 Hendry WF. Kidney. In: Chisholm GD, ed. Tutorials in postgraduate medicine: urology. London: Heinemann Medical, 1980:173-91.

3 Wickham JEA. Conservative renal surgery for adenocarcinoma. The place of bench surgery. Brf Urol 1975;47:25-36.

(Accepted 28 September 1981)

Department of Urology, Freeman Hospital, Newcastle upon Tyne NE7 7DN

C P ST J NEWMAN, MB, FRCS, senior registrar in urology and renal transplantation (present appointment: consultant surgeon, Shotley Bridge General Hospital, Consett, Co Durham)

D M ESSENHIGH, MCHIR, FRCS, consultant urologist

\section{Correction}

\section{Prognosis of isolated seizures in adult life}

An error occurred in this paper by Dr P G Cleland and others (21 November, $p$ 1364). In the third paragraph of "Subjects, methods, and results" the second sentence should have read: "In five $(12 \%)$ of the former and six of the latter group. ...", 